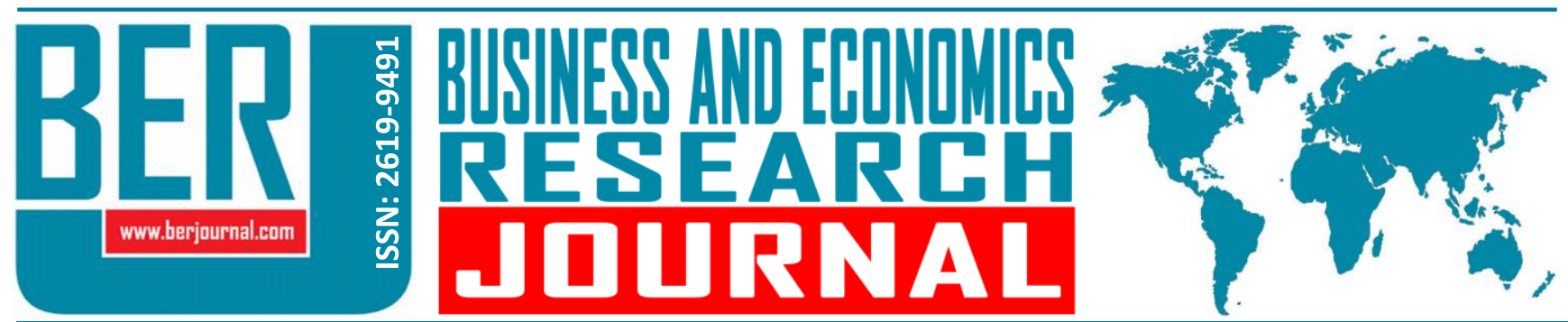

Business and Economics Research Journal Vol. 9, No. 4, 2018, pp. 787-798 doi: 10.20409/berj.2018.115

\title{
Is There a Financial Accelerator Mechanism in the Turkish Banking Industry?
}

\section{Ekin Ayse Ozsuca ${ }^{a}$}

Abstract: This paper empirically investigates the cyclical behavior of price-cost margins for Turkish banks over the 2002q1-2017q3 period by exploiting dynamic panel data modeling approaches. The estimation results indicate that margins behave countercyclically during economic fluctuations. It appears that Turkish banks' price-cost margins tend to stay high acting countercyclical during economic downturns, which may limit the supply of loans and thereby, cause a further reduction in production, deepening the contraction. Specifically, several bank-specific characteristics, that is; banks' liquidity, capitalization and size, together with the monetary policy and market concentration in the banking industry are found to be crucial in explaining the countercyclical behavior of net interest margins in Turkey. Furthermore, the recent global financial crisis in the late 2008 seems to have a considerable effect on the banks margins as well. Overall, these findings provide evidence for the existence of "financial accelerator" at work in the Turkish economy during the period under investigation.

\author{
Keywords: Price-Cost \\ Margins; Business Cycles; \\ Financial Accelerator; Turkish \\ Banking Industry; Dynamic \\ Panel Data \\ JEL: E32, E44, G21
}

\section{Introduction}

Being at the heart of the financial system, banking industry may have significant effects on the real economic activity. Banks as financial intermediaries channel funds from savers to borrowers who will make productive investments which in turn contribute to economic growth. Financial intermediation becomes especially important during business cycle fluctuations. Banks acting as mitigating or amplifying mechanisms in business cycles play a crucial role for macroeconomic stability and may be the source of potential fluctuations in the real economy.

This is closely related with the financial accelerator mechanism introduced by Bernanke, Gertler, \& Gilchrist (1996). In their paper, they study the propagation of aggregate fluctuations with an emphasis on the role of credit-market imperfections. They state that the effects of an initial real or monetary shock are amplified in the economy by changes in the creditworthiness of the borrowers through asymmetric information. With credit being procyclical, it becomes more expensive and less available during downturns, which further exacerbates the recession by making investment and production to shrink. As a result, relatively small economic shocks which may be short-living in nature are amplified and propagated by endogenous changes in the credit markets, which could result in persistent fluctuations in the economy. 
At the heart of the aforementioned hypothesis is the concept of external finance premium, which is defined by Bernanke and Gertler (1995) as the difference between external and internal funding costs. Bernanke and Gertler (1989) as well as Bernanke et al. (1996) state that the financial condition of the borrower should be the main factor in determining the external finance premium. Any change in the condition of balance sheets is bound to have an impact on the borrower's decisions regarding investment and spending. More specifically, any factor causing deterioration in borrowers' financial position (i.e.; higher external finance premium) will increase its debt service and cause a reduction in its value of net worth, which end up with a higher real cost of borrowing and accordingly lower level of investment. Consequently, accelerator effects emerge as weakened balance sheet strength in bad times shrink investment demand, which in turn tends to amplify during contractions. Therefore, the amplification arises as a result of differences in net worth of borrowers, thereby a change in the external finance premium.

Recently, a stand of literature has noted that banks' price-cost margins ${ }^{1}$ can be employed as a measure for the premium on external financing that banks charge to enterprises, as the banks' marginal cost of funds are considered to be a favorable representative of the marginal cost of internal funding undertaken by the firms (Altunbaş, Tommaso, \& Thornton, 2016). Related to the financial accelerator mechanism, it can be stated that the cyclicality of bank margins is of great importance in various stages of business cycles. If the price-cost margin tends to remain high acting countercyclically during contractions, firms will hardly access to cheap credit, which will cause them to delay their investment decisions. This will in turn leads to a further reduction in production deepening the recession.

The study of the link between bank' price-cost margins and business cycle fluctuations constitutes a significant element of the macro-prudential analysis as well. Since banking sector is a significant factor in the analysis of business cycles and monetary policy transmission, the cost of intermediary activities measured by net interest margins and cyclical properties of these margins over fluctuations will provide valuable insights about the interaction between the economy's financial and real sectors, that may help policymakers to better formulate their policies. This issue becomes especially important with the onset of the 2008 global economic downturn. The recent credit crunch faced by the world has led macroeconomists to reconsider the dynamic interrelation between the economy's financial and real sectors. Prior to the global economic crisis, central banks and policy makers traditionally pursue the objective of price stability with a little emphasis on financial stability aspect, mostly disregarding the functioning of the financial sector along with the banking industry. However, as this turmoil shows that macroeconomic and financial stability are highly interrelated, banking sector's role in macroeconomic balances together with the importance of macro-prudential regulations and supervision become more evident. Hence, there is a revived interest in examining the cyclical behavior of the bank margins in this respect.

Against this background, analyzing whether banks act as mitigating or amplifying business cycle fluctuations can advance our understanding of the banking sector's potential impact on the real economic activity in Turkey. In an attempt to do so, this study uncover the cyclicality of Turkish banks' price-cost margins from 2002q1 to 2017q3. In other words, this paper endeavors to provide evidence whether there exists a "financial accelerator" operating in the Turkish economy during this sample period. An important point to mention is that the period under investigation has some distinguishing features. The time span after 2001 crisis constitutes a novel era with changing financial structure and macroeconomic fundamentals, in conjunction with alterations in the way macroeconomic policies are adopted in the economy of Turkey. In addition, it covers the 2008 global financial crisis and more specifically; the time interval when its adverse effects are seriously manifested on the Turkish economy as well. Hereunder, the cyclical behavior of pricecost margins is empirically investigated by examining a data set of an unbalanced panel of banks operating in Turkey between 2002q1 and 2017q3, utilizing three different price-cost margin measures and two alternative business cycle indicators. While macroeconomic policy-related and industry-specific factors that may have an effect on banks' net interest margins are taken into account, the behavior of price-cost margins over economic fluctuations is further investigated by adopting several bank-specific factors, which are size, liquidity and capitalization, as explanatory variables, based on the information from banks' balance sheet 
and income statements. Lastly, the paper addresses to any likely effect of the 2008 global economic crisis on net interest margins.

This paper contributes to the sparse existing research on the cyclical behavior of Turkish banks' interest margins in numerous ways. First of all, time span of the analysis covers a longer period when compared with the all other studies on this issue. In addition to that, it aims to examine the existence of any effect of the 2008 global financial crisis on Turkish banks' price-cost margins. Furthermore, it is the first paper that not only investigates the behavior of price-cost margins over business cycles by controlling industryspecific variables but also explores the effects of several bank-specific characteristics on margins during 2012q1-2017q3 period for Turkey. Apart from these, this paper adds to the limited existing literature which presents empirical evidence about cyclicality of price-cost margins for an emerging economy, given the fact that previous empirical studies mainly focus on advanced countries or a cross-section of countries.

The remainder of the paper is structured as follows: A review of the related empirical literature is outlined in Section 2.The data set, econometric model and methodology are presented in Section 3. Empirical evidence is discussed in Section 4. Last section concludes.

\section{Literature Review}

While a vast body of literature examines net interest margins of the banking industry ${ }^{2}$ in several aspects, recently a couple papers scrutinize the behavior of banks' price-cost margins so as to test for the financial accelerator mechanism explained in the Introduction part. The first study that uses bank price-cost margins over business cycle fluctuations is by Aliaga-Diaz and Olivero (2010). For the US banking industry over the period 1984-2005, they measure co-movement between bank margins and business cycle indicators by using a VAR forecast error-based methodology. Their results show the countercyclicality of price-cost margins with respect to GDP and total loans after controlling for credit risk, the term structure of interest rates and monetary policy. They interpret this evidence as a support for the existence of a financial accelerator in US banking industry. In their later study, Aliaga-Diaz and Olivero (2011) build an empirical model for the determinants of the countercyclical behavior of banks' price-cost margin by employing a panel of US banks over the period 1979-2005. With the intend of providing additional explanations for this behavior, authors show that margins are consistently countercyclical regarding per capita GDP and total bank loans and moreover, monetary policy, the economy's financial depth, interest rate risk, banks' capitalization, and the share of total assets held by large banks are found to have remarkable effect on margins during the cycle.

Outside of the US, Altunbaş et al. (2016) adds to the empirical literature by analyzing the cyclicality of banks' price-cost margins in a panel dataset of banks in 15 European countries over the period 1989-2012. Their results report strong support for the countercyclical behavior of margins in European banking when monetary policy, interest rate risk, and various industry-specific and bank-specific variables are controlled. The countercyclicality of margins is also found to be robust to the effect of euro adoption and the Basel II Accords. As a result, their results indicate that financial accelerator mechanism is at work in European economies.

As for the Turkish economy, there are many studies that seek to shed light on the main determinants of net interest margins in the banking sector ${ }^{3}$, but there are a few that examines the cyclicality of bank's price-cost margins. To the best of our knowledge, the only papers are Turgutlu (2010) and Aydemir and Guloglu (2016). Among them, Turgutlu (2010) analyzes the cyclical behavior witnessed in the Turkish banks' price-cost margin between 2002 and 2008. Utilizing dynamic panel data analysis, the paper provides evidence for the countercyclicality in bank margins. Moreover, control variables such as monetary policy, market structure and economy's financial depth turned out to be key determinants of banks' price-cost margins during the related period. In their more recent paper Aydemir and Guloglu (2016) utilize bank spreads as an indicator of efficiency of financial intermediation to analyze how credit and liquidity risk at the same time being influential over bank spreads during economic fluctuations in Turkey from 2002 to 2013. Their empirical results show that both of the risks do have an impact on bank spreads, while credit risk being 
more important than liquidity risk in determining bank spreads. Furthermore, it is found that the effects of these risks on bank spreads are different over business cycles. More specifically, liquidity risk is found to have more significant impact during downturns, while credit risk turned out to have more significant effect during booms.

\section{Data Set, Econometric Model and Methodology}

In the study, the following empirical specification is considered to examine the cyclicality of banks' price cost margins in Turkey:

$$
P C M_{i, t}=\alpha+\gamma P C M_{i, t-1}+\theta B C_{i, t}+\beta_{1} Z_{t}+\beta_{2} X_{i, t}+\eta C R I S I S_{t}+\varepsilon_{i, t}
$$

with $i=1, \ldots \ldots, N$ and $t=1, \ldots . ., T$ where $N$ is the number of banks and $T$ is the final quarter. Here, $P C M_{i, t}$ represents banks' price-cost margins and, three alternative measures of margins are used following AliagaDiaz and Olivero (2011). These measures are computed as (i) the difference between the ratio of interest income on loans to the volume of loans and the ratio of interest expense on deposits to the volume of deposits (PCM 1); (ii) the ratio of the difference between interest income and interest expenses to total assets (PCM 2); (iii) the ratio of the difference between interest income and interest expenses to total loans (PCM 3).

$B C_{i, t}$ denotes the business cycle indicator which is incorporated as an explanatory variable to capture the cyclical variation in banks' margins during economic fluctuations period. Two alternative measures for business cycle are used; the growth rate of real GDP (GDP) and the total bank loans (LOANS), which is cyclically adjusted by employing Hodrick-Prescott filter. The first indicator is a macroeconomic measure that directly illustrates the aggregate economic conditions, while the second measure is included to take into account the fact that total loans may better represent the behavior of aggregates, like investment and production, as they heavily rely on bank financing (Aliaga-Diaz \& Olivero, 2011). The estimated value of the business cycle variable coefficient is the primary focus of the analysis. Accordingly, a negative (positive) and significant coefficient attached to the business cycle indicator suggests countercyclicality (procyclicality) of the price-cost margins.

Following the previous literature, several regressors are included into the empirical model to control for macroeconomic, industry-specific and bank-specific factors. First, the vector $Z_{t}$ in Eq. (1) incorporates variables to account for monetary policy and bank industry-specific characteristics, i.e. market concentration. Monetary policy is related with price-cost margins of banks in several aspects. Firstly, it is postulated that deposits rates tend to have more inertia than loan rates, which implies a positive impact of monetary policy shocks on margins (Angelini \& Cetorelli, 2003). Except this, monetary policy can be influential on the supply of loans and thereby, on price-cost margins through bank lending channel of monetary policy. A monetary tightening that reduces banks' deposits restricts the supply of loanable funds. Consequentially, bank's ability to lend decreases and the cost of borrowing increases, which in turn leads to higher price-cost margins (Aliaga-Diaz \& Olivero, 2011). In other words, higher interest rates due to a monetary policy contraction would cause a rise in the cost of capital, and eventually banks adjust their pricing decisions about loans and deposit which results in higher banking sector margins. Hence, monetary policy is anticipated to exert a positive impact on price-cost margins. Towards this end, three month interbank rate is used to control for the impact of monetary policy (INTRATE).

Regarding industry specific factors, Herfindahl-Hirschman index (HHI) is incorporated to account market concentration, which may have an important impact on banks' price-cost margins. Accordingly, Herfindahl-Hirschman index for the Turkish banking sector is computed as the sum of squared market shares in terms of total assets of all banks. Earlier studies on banking sector concentration and bank margins display mixed results. Since higher values of $\mathrm{HHI}$ suggests to greater extent of concentration and conceivably lower levels of competition, large banks can have more pricing power in their lending practices, so it is reasonable to presume a positive relationship between industry concentration and banks' price-cost margins. On the other hand, there are some caveats regarding concentration ratios including $\mathrm{HHI}$ in the sense that they fail 
to account for the impact of product differentiation and geographic advantages that enable some banks to exert monopoly power over interest rates apart from their market share (Aysan et al., 2009). In that case price-cost margins and market concentration can have a negative relationship. Hence, the expected sign of the coefficient of $\mathrm{HHI}$ variable in regression is ambiguous.

Finally, $X_{i, t}$ is a vector which comprises bank-specific variables. As potential determinants of pricecost margins, various bank-specific characteristics specifically; size, liquidity and capitalization, are incorporated into the model. Liquidity (LIQ) is measured by the ratio of liquid assets to total assets. Since liquid assets such as cash and government securities are less likely to yield to high returns, banks holding more liquid portfolios tend to receive less net interest revenue when compared with their peers holding less liquid assets such as loans. Therefore, liquidity is expected to have a negative impact on price-cost margins. Capitalization (CAP) is captured by shareholders' equity to total assets ratio, and introduced into specification as capital adequacy is conjectured to show risk-aversion behavior of the bank. More specifically, more riskaverse banks are likely to have higher capital ratios. Since holding equity is more costly than holding debt, risk-averse well-capitalized banks tend to charge higher margins than risk neutral banks (Aliaga-Diaz \& Olivero, 2011). In addition, banks with higher capital are considered to be less risky, thus they are perceived to have lower bankruptcy costs, which decreases their funding costs, contributing to higher net interest margins (Abreu \& Mendes, 2001). Hence, the coefficient of this variable is predicted to be positive. Finally as an indicator of size (SIZE), the logarithm of banks' total assets is incorporated into the regression. The expected sign of the coefficient is uncertain, since while it is possible for larger banks to exert monopoly power in charging higher prices, they may also benefit from economies of scale and reduce their cost of credit, which may result in lower interest margins (Maudos \& Guevera, 2004). It can be claimed that in the case of scale efficiencies, large-sized banks tend to have access to more sources of funds and accordingly can raise capital at lower costs, which will translated into narrower net interest margins. In addition to these regressors, a dummy variable is incorporated into the specification for testing the cyclicality Turkish banks' price-cost margin during the 2008 global financial crisis. The crisis dummy (CRISIS) takes value 1 at the first quarter of 2009 and 0 otherwise. When the evolution of the net interest margins over the sample period is examined, a significant rise in the net interest margin is observed in the first quarter of 2009. The global financial crisis causes a deterioration in the risk perceptions and hence induce a decrease in loans and results in higher interest margins (Aysan, 2009; Maudos \& Guevera, 2004; Saunders \& Schumacher, 2000). As a result, this variable is expected to enter into equation (1) with a positive coefficient.

The empirical analysis relies on a quarterly unbalanced panel data set of commercial banks operating in Turkey between 2002q1-2017q3. The sample is constructed to cover all of the banks in Turkey that have been worked at least four quarters over the period in question to ensure broad coverage. The sample is then adjusted by imposing an outlier rule in order to exclude the observations for which data on main bank-level variables of interest do not exist or have extreme values. Development and investment banks, as well as participation banks were excluded from the sample, as they do not entirely match with the theoretical framework regarding the financial accelerator mechanism, on account of having a different financing structure than commercial banks as well as the fact that they don't accept deposits. The final sample contains 42 banks which have been operative in Turkey throughout the period investigated and considered to be highly representative since it comprises for nearly $95 \%$ of the banking industry's total assets by the third quarter of 2017.

Quarterly data of the banks, including balance sheet and income statement, have been gathered through the Banking Association of Turkey. The three month interbank rate and seasonally adjusted real GDP data are obtained from OECD Economic Outlook database. Definitions of the variables employed in the analysis plus statistical summary for the final sample are given in Table 1 and Table $2^{4}$, respectively. 
Table 1. Description of the Variables

\begin{tabular}{|c|c|c|}
\hline Variable & Notation & Description \\
\hline Price cost margin 1 & PCM1 & $\begin{array}{l}\text { Difference between the ratio of interest income on loans to the } \\
\text { volume of loans and ratio of interest rate expense on deposits to } \\
\text { the volume of deposits }\end{array}$ \\
\hline Price cost margin 2 & PCM2 & The ratio of net interest revenue to total assets \\
\hline Price cost margin 3 & PCM3 & The ratio of net interest revenue to total loans \\
\hline Real GDP & GDP & $\begin{array}{l}\text { Quarter-on- quarter changes in real GDP at constant } 1998 \text { prices, } \\
\text { seasonally adjusted }\end{array}$ \\
\hline Bank loans & LOANS & Total bank loans, detrended (millions) \\
\hline $\begin{array}{l}\text { Policy rate } \\
\text { Herfindahl- }\end{array}$ & INTRATE & Short-term interbank rate \\
\hline Hirschman index & $\mathrm{HHI}$ & The sum of squared assets market share of banks \\
\hline Liquidity & LIQ & The ratio of liquid assets to total assets \\
\hline Capitalization & CAP & The ratio of shareholders 'equity to total assets \\
\hline Size & SIZE & Log of total assets (million) \\
\hline Crisis dummy & CRISIS & Dummy variable for the 2008 global crisis \\
\hline
\end{tabular}

Table 2. Summary Statistics

\begin{tabular}{|cccccc|}
\hline Variables & $\begin{array}{c}\text { No. of } \\
\text { Observations }\end{array}$ & Mean & Std. Dev. & Min. & Max. \\
\hline PCM1 & 1800 & 1.39 & 5.78 & -30.75 & 21.47 \\
PCM2 & 1832 & 3.06 & 2.84 & -21.69 & 28.02 \\
PCM3 & 1731 & 8.31 & 12.89 & -55.64 & 88.37 \\
GDP & 1832 & 1.49 & 2.05 & -5.10 & 5.60 \\
LOANS & 1832 & 0.06 & 28.4 & -60.10 & 83.90 \\
INTRATE & 1832 & 14.17 & 12.01 & 1.50 & 54.73 \\
HHI & 1832 & 921.31 & 41.02 & 863.22 & 993.26 \\
LIQ & 1832 & 37.21 & 19.52 & 2.90 & 97.70 \\
CAP & 1832 & 16.53 & 15.09 & -59.09 & 92.40 \\
SIZE & 1832 & 15.59 & 2.23 & 8.27 & 19.83 \\
\hline
\end{tabular}

Previous literature indicates that bank margins tend to be highly persistent over time- i.e., the past values of the price-cost margins determine the current level of the margin. Moreover, as Yılmaz (2017) points out, the average maturity for deposits together with the average maturity period for the commercial loans, which are usually priced with the floating interest rate structure and constitutes a significant portion of banks' loan portfolio, happen to be around three months in Turkey. Additionally, banks offer part of their new loans and deposits in the form of roll-overs, while trying to keep a certain spread between their loans and deposits. Therefore, it is very likely that the banks' net interest margins have a persistent nature and the current levels of margin might be affected by the past realizations. Apart from that, as emphasized by Altunbaş et.al (2016), the direction of causality is not clear between the bank margins and developments in business cycles. Specifically, aggregate economic activity as represented by business cycle indicators can be a function of the credit cost calculated by using bank margins (Aliaga-Diaz \& Olivero, 2011). Therefore, this potential reverse causation needs to be analyzed as a particular case of endogeneity.

Implementing a dynamic panel model, which counts lagged value of the dependent variables among regressors, while taking account of the persistent and dynamic nature of banks' price-cost margins, would provide a better solution in overcoming these problems. Accordingly, equation (1) is estimated by using the dynamic panel generalized methods of moments (GMM) methodology developed by Arellano and Bover 
(1995) and Blundell and Bond (1998). This estimator yields efficient and unbiased estimates, as long as the dynamic regression model is not subject to second order serial correlation and that the instruments which have been employed are valid. Therefore, AR tests are conducted for first and second order autocorrelation. Finally, the Sargan test of over-identifying restrictions is used for assessing the instruments' validity.

\section{Estimation Results}

The results for the three price-cost margins of banks are presented in Table 3. For each of the margins, the results comprising the two different business cycle indicators- real GDP growth and cyclically adjusted total loans are reported in the first and second column, respectively.

Table 3. Estimation Results

\begin{tabular}{|c|c|c|c|c|c|c|}
\hline \multirow[b]{2}{*}{ Constant } & \multicolumn{2}{|c|}{ Margin 1 (PCM1) } & \multicolumn{2}{|c|}{ Margin 2 (PCM2) } & \multicolumn{2}{|c|}{ Margin 3 (PCM3) } \\
\hline & $3.980 * * *$ & $3.140 * * *$ & $2.730 * * *$ & $3.870^{* *}$ & $3.760 * * *$ & $3.690 * * *$ \\
\hline & $(4.440)$ & $(8.220)$ & (1.140) & (3.550) & $(3.460)$ & (3.362) \\
\hline \multirow[t]{2}{*}{ PCM (-1) } & $0.121^{* * *}$ & $0.118^{* * *}$ & $0.267^{* * *}$ & $0.265^{* * *}$ & $0.442 * * *$ & $0.440 * * *$ \\
\hline & $(0.014)$ & $(0.015)$ & $(0.011)$ & $(0.010)$ & $(0.006)$ & $(0.006)$ \\
\hline \multirow[t]{2}{*}{ GDP } & $-0.308 * * *$ & & $-0.780 * * *$ & & $-0.188 *$ & \\
\hline & $(0.009)$ & & 0.004 & & 0.005 & \\
\hline \multirow[t]{2}{*}{ LOANS } & & $-0.0002^{*}$ & & $-0.0005^{* *}$ & & $-0.0003 *$ \\
\hline & & $(0.0005)$ & & $(0.0003)$ & & $(0.0001)$ \\
\hline \multirow[t]{2}{*}{ INTRATE } & $-0.248 * * *$ & $-0.207 * * *$ & $0.0312 * * *$ & $0.028 * * *$ & $0.056 * * *$ & $0.074 * * *$ \\
\hline & $(0.010)$ & $(0.014)$ & (0.009) & $(0.010)$ & $(0.013)$ & $(0.011)$ \\
\hline \multirow[t]{2}{*}{$\mathrm{HHI}$} & $-0.017 * * *$ & $-0.016^{* * *}$ & $-0.010 * * *$ & $-0.011 * * *$ & $-0.034 * * *$ & $-0.035^{* * *}$ \\
\hline & $(0.001)$ & $(0.002)$ & $(0.007)$ & $(0.001)$ & $(0.001)$ & $(0.001)$ \\
\hline \multirow[t]{2}{*}{ SIZE } & $-0.511 * * *$ & $-0.471 * * *$ & $-0.877 * * *$ & $-0.859 * * *$ & $-0.920 * * *$ & $-0.824 * * *$ \\
\hline & $(0.302)$ & $(0.305)$ & $(0.502)$ & $(0.042)$ & $(0.538)$ & $(0.541)$ \\
\hline \multirow[t]{2}{*}{ LIQ } & $-0.011^{*}$ & $-0.019^{*}$ & $-0.007^{* *}$ & $-0.006^{* *}$ & $-0.101^{*}$ & $-0.096 *$ \\
\hline & $(0.007)$ & $(0.010)$ & $(0.003)$ & $(0.004)$ & $(0.007)$ & $(0.008)$ \\
\hline \multirow[t]{2}{*}{ CAP } & -0.055 & -0.032 & $0.065^{* * *}$ & $0.069 * * *$ & $0.097^{* * *}$ & $0.107^{* * *}$ \\
\hline & $(0.121)$ & $(0.009)$ & $(0.003)$ & $(0.004)$ & $(0.010)$ & $(0.010)$ \\
\hline \multirow[t]{2}{*}{ CRISIS } & $0.292^{*}$ & $0.360^{* *}$ & $1.700 * * *$ & $1.890 * * *$ & $2.401^{* * *}$ & $2.885^{* * *}$ \\
\hline & $(0.415)$ & $(0.408)$ & (0.134) & $(0.128)$ & $(0.116)$ & $(0.057)$ \\
\hline No. of observations & 1712 & 1712 & 1768 & 1768 & 1729 & 1729 \\
\hline Sargan test ( $p$-value) & 0.363 & 0.341 & 0.225 & 0.388 & 0.439 & 0.431 \\
\hline $\operatorname{AR}(1), \operatorname{AR}(2)$ (p-value) & $0.001,0.173$ & $0.001,0.176$ & $0.001,0.886$ & $0.001,0.745$ & $0.003,0.871$ & $0.003,0.879$ \\
\hline
\end{tabular}

Note: $* * * * *, *$ indicate that coefficients are statistically significant at the $1,5,10 \%$ level, respectively. The values in round brackets below the estimated coefficients are the robust standard errors (clustered at the bank level).

In all of the specifications, business cycle regressors yield statistically significant coefficients with expected signs. Business cycle indicators, which are proxied by real GDP growth and total bank loans, have negative and significant coefficients. This finding indicates that when the economy goes through a contraction period, Turkish banks increase their price-cost margins. In other words, the net interest margins of Turkish banks appear to be countercyclical after several macroeconomic, industry and bank-specific variables are controlled for. This countercyclical behavior indicates that in times of bad macroeconomic stance credit supply might shrink, causing businesses to decrease or postpone their investments, which in turn, further aggravates the downturn in the economy. A noteworthy finding is that, coefficient estimates of cyclically adjusted total loans have smaller magnitude than that of real GDP growth. This finding is contrary 
to the result put forward by Turgutlu (2010) as bank margins are insensitive to GDP growth rate and instead using loans indicator is superior in capturing business cycles fluctuations regarding Turkish banking sector. Furthermore, banks' price-cost margins appear to be persistent given the positive and statistically significant coefficients of their lagged values in all of the models confirming the dynamic nature of interest margins. First lag of the margins appears to have an impact in determining the contemporaneous values, which can be interpreted as there is a rise in the countercyclicality of price-cost margins over time. In addition, the coefficient of the lagged value is found to be close to 0 in all of the estimations except for the specifications for the third price-cost margin, indicating that bank interest margins adjust in a high pace. That is to say, Turkish banking sector operates under a fairly competitive environment in the sense that higher margins would not act as entry barriers. These results give evidence of countercyclical behavior of Turkish banks' price-cost margins for 2002q1-2017q3 and accordingly, it points out to an operational financial accelerator mechanism in the Turkish economy during this period.

As shown in the results reported on Table 3, the estimated coefficient of three month interbank rate as monetary policy indicator is positive and statistically significant for the models comprising the second and third price-cost margins, whereas the coefficient turns out to be negative for the specification using the first margin. The positive and significant coefficient has important implications since the three-month interbank rate can be thought as being not only a measure of banks' short-term borrowing costs and displays banking sector's liquidity position, but it is also an indicator of Central Bank of the Republic of Turkey's policy rate as well. This result shows that when interbank rate increases, the cost of borrowing increases and as result of that Turkish banks charge higher prices for lending their clients and widen the margins. Furthermore, this statistically positive coefficient suggests an operative bank lending channel of monetary policy transmission during the period under analysis. Therefore, monetary authorities seem to have power to effect Turkish banks' price-cost margins as monetary policy stance proxied by interbank interest rates is found be significant in determining pricing behavior of banks regarding their loans and deposits. However, while the interbank rate is found to be significant for the first price-cost margin, the direction of the relationship is contrary to the previous expectations. This result can stem from the fact that first margin takes account specifically banks' interest earning and interest bearing activities on loans and deposits markets, whereas the second and third margins are broader in the sense that they include all interest earning and interest expense activities of the bank. Therefore, this negative coefficient indicates that when solely interest revenues on loans and interest expenses on deposits together with their volumes are considered, banks might not reflect higher borrowing costs as wider margins to their loan and deposit customers.

Industry-specific and bank-specific explanatory variables have meaningful coefficients. The estimation results show that impact of market concentration on banks' margins is negative and statistically significant. That is, as the HHI increases- i.e. concentration in the banking sector rises; banks narrow their margins in Turkey. This result can be interpreted as higher levels of market concentration in the Turkish banking sector reflects higher share of total assets held by large banks, which are found to price lower net interest margins according to several studies including Ho and Saunders (1981), Maudos and Guevara (2004), Gerlach, Peng and Shu (2005), Hesse (2007), Fungacova and Poghosyan (2011), Almarzoqi and Naceur (2015). Therefore, it could be inferred that higher concentration in the industry does not manifests itself as large banks exerting monopoly power in their pricing policy, i.e. charging higher credits rates and lower deposits rates, but rather they seem to extract economies of scale and create efficiency gains in terms of lower costs for consumers. Furthermore, as stated by Turgutlu (2010) this result may also stem from the fact that large banks get involved in big long-run investment projects that cannot be adjusted quickly in the short-term.

Turning to the effects of bank-specific variables, estimation results for all regression specifications indicate a significantly negative coefficient for liquidity. This finding suggests that liquidity of Turkish banks' portfolios narrows price-cost margins. Put differently, banks with high holdings of liquid assets tend to charge lower rates on loans and are likely to earn less interest revenue as risk-free liquid assets yield low returns. Therefore, this finding shows that highly liquid Turkish banks do not seem to widen their margins to cover the cost of holding significant amount of liquid assets in their portfolio. As table 3 shows, capitalization variable enters positively into all models, but its coefficient is statistically significant just for the second and 
third price-cost margin specifications and it turns out to be insignificant for the first margin. This finding appears to be in line with a priori expectation as higher equity-to- total asset ratio is considered to be an indicator of confidence against potential risks and thereby the bank's financial strength, so well-capitalized banks tend to have low level of insolvency risk which reduce their need for external funding as they have excess capital that serve as buffer against the negative impacts of shocks and/or enable them to raise external funds with lower costs as well. This result can also be interpreted that the risk aversion behavior displayed by Turkish banks with high capital ratios are translated into higher margins to cover the cost of the extra risk they take. Therefore, the outcome regarding capitalization suggests that the risk-averse banks holding higher levels of capital in Turkey have lower funding costs which results in wider price-cost margins. This evidence is in line with the relatively high levels of price-cost margins in Turkey as Turkish banking system has remarkably high capital adequacy ratios. Finally, among the bank specific variables, coefficient of the size variable enters all regression specifications as being negative and statistically significant. In other words, larger banks appear to have lower net interest margin in Turkey. This result could be interpreted as big Turkish banks seem to achieve economies of scale that enable them to provide more credit while charging lower markups. This is line with the previous result regarding the effect of market concentration on bank margins and also with the findings in the aforementioned related literature there. In sum, all of the bank characteristics examined in the analysis are found to be economically and statistically significant determinants of the three alternative price-cost margins for Turkish banks during the sample period.

Lastly, in each model, the 2008 global crisis dummy yields a positive and statistically significant coefficient as expected, implying that the global financial turbulence has a major impact on the Turkish banks' price-cost margins. More specifically, Turkish banks appear to increase their margins in response to the global downturn, which could be the result of the deterioration in their risk perceptions.

\section{Conclusion}

In this study, the behavior of Turkish banks' net interest margins over business cycles is examined for the period 2002 -2017. Using quarterly bank-level data, a dynamic panel data model is estimated by the GMM estimator proposed by Arellano and Bover (1995) and Blundell and Bond (1998). The analysis was made employing three different price-cost margin measures and two business cycle indicators: real GDP growth and cyclically adjusted bank loans.

The estimation results indicate that price-cost margins of the Turkish banks act in a counter-cyclical manner over economic fluctuations during the related period. This result is robust when several macroeconomic, industry-specific, bank-specific variables and to the impact of the global crisis are controlled for. Overall, the empirical results suggest banks' liquidity, capitalization and size together with the monetary policy and market concentration in the banking industry are crucial in the explaining the countercyclical behavior of banks' net interest margins in Turkey. Moreover, the 2008 global financial crisis seems to have a significant effect on margins as well. This evidence supports the recent results found regarding the US and European banks and promotes the existence of a financial accelerator in the Turkish banking system. Furthermore, this study adds to the large body of literature in macroeconomic theory that makes use of countercyclical margins and accelerator as a mechanism for the propagation of aggregate shocks.

The findings of the study have great importance especially for developing countries including Turkey whose financial sectors are heavily dependent on the banking industry. Even though non-bank financial institutions are recently gaining importance in Turkey, total assets of the banking system still account for 81 percent of those of the institutions in the financial sector as of late 2016. Therefore, while banks in Turkey have traditionally played the main role in financial intermediation and net interest margins are accepted to be significant indicator for the cost of that intermediation process, analyzing main components of the pricecost margins may give essential information regarding Turkish banking efficiency in translating savings into investments. Furthermore, the countercyclical behavior of net interest margins over business fluctuations highlights the financial sector's role in macroeconomic stability along with economic growth given the high dependency of small and medium-sized enterprises in the private sector to bank financing in Turkey. With regard to policies, this counter-cyclical nature may have additional implications for the Turkish regulatory 
authorities in terms of the measures that they can take for proper stabilization. Firstly, Central bank should take into account the conditions of the banking sector when determining a new monetary policy, as the empirical results indicate that monetary policies and efficiency of the banking system are interrelated, which in turn contribute to macroeconomic and financial stability. Appropriate policies that take into account this asymmetric nature of credits during economic fluctuations will offset or mitigate some of the negative consequences in the real economic activity. Moreover, the fact that bank specific characteristics including the size, capitalization and liquidity are prominent in determining Turkish banks' price-cost margins displays the impact that effective regulation and supervision have over these characteristics. Efficient regulation and supervision will therefore contribute to the efficiency of the system in terms of intermediation. Apart from these microregulation policies, the results of the study not only underline the importance of macroprudential regulations and supervision, but they also give sense about the relative effectiveness of the new policies implemented on the onset of the global financial crisis. In other words, the findings elucidate the significance of the macro-prudential policies adopted by Central Bank of the Republic of Turkey towards the end of 2010. Extending the analysis to non-financial sectors and examining the relationship between price-cost margins and business cycles in Turkish manufacturing and/or services sectors could enhance our understanding about the role of the business cycles on the overall economy. Moreover, as there is lack of evidence regarding the existence of financial accelerator mechanism for developing countries, it would be worthwhile to conduct similar analysis for such countries and also a more comprehensive cross-country analysis as well.

\section{End Notes}

1. For the studies in the industrial organization literature that examine the relationship between price-cost margins and business cycle fluctuations see Green and Porter (1984), Rotemberg and Saloner (1986), Domowitz, Hubbard and Petersen (1986a,b), Rotemberg and Woodford (1991), Prince and Thurik (1992), Machin and Van Reenen (1993), Haskel, Martin and Small (1995), Portier (1995), Oliveira Martins, Scarpetta and Pilat (1996), Chand and Sen (2000), Lima and Resende (2004), Culha and Yalçın (2005), Nekarda and Ramey (2013).

2. The pioneering work by Ho and Saunders (1981) constitutes the basis for the literature studying on the main components of net interest margins. In their dealership model, banks operating in homogenous deposit and loan markets, charge a positive interest spread to maximize their profit since they are faced with transactions uncertainty due to the randomness of loan demand and deposit supply. The authors show that this pure spread depends on four factors: the degree of bank management's risk-aversion, the average size of transactions undertaken by the bank, market structure, and the dispersion of interest rates on loans and deposits. The literature stemming from Ho and Saunders (1981) further extended by works of several scholars including McShane and Sharpe (1985), Allen (1988), Angbazo (1997), Saunders and Schumacher (2000), Maudos and Guevera (2004).

3. For studies examining the determinants of net interest margins in the Turkish banking industry, see Kaya (2002), Erol (2007), Abbasoglu, Aysan and Gunes (2007), Aysan, Dalgıc and Demirci (2010), Ozdincer and Ozyıldırım (2010), Ugur and Erkus (2010), Kansoy (2012), Konar (2014), Yılmaz (2017), Yuksel and Zengin (2017).

4. Table 2 summarizes the data without excluding the outliers.

\section{References}

Abbasoglu, O. F., Aysan, A. F., \& Gunes, A. (2007). Concentration, competition, efficiency and profitability of the Turkish banking sector in the post-crises period, MPRA paper 5494, University Library of Munich, Germany.

Abreu, M., \& Mendes, V. (2001, May). Commercial bank interest margins and profitability: evidence for some EU countries. Pan-European Conference Jointly Organised by the IEFS-UK \& University of Macedonia Economic \& Social Sciences, Thessaloniki.

Aliaga-Diaz, R., \& Olivero, M. P. (2010). Is there a financial accelerator in US banking? Evidence from the cyclicality of banks' price-cost margins. Economic Letters, 108, 167-171.

Aliaga-Diaz, R., \& Olivero, M. P. (2011). The cyclicality of the price-cost margins in banking: an empirical analysis of its determinants. Economic Inquiry, 49 (1), 26-46. 
Allen, L. (1988). The determinants of bank interest margins: A note. Journal of Financial and Quantitative Analysis, 23(2), 231-235.

Almarzoqi, R., \& Naceur, M. S. B. (2015). Determinants of bank interest margins in the Caucasus and Central Asia, IMF Working Papers 15/8, International Monetary Fund.

Altunbaş, Y., Tommaso, C. D., \&Thornton, J. (2016). Is there a financial accelerator in European banking?. Finance Research Letters, 17, 218-221.

Angbazo, L. (1997). Commercial bank net interest margins, default risk, interest-rate risk, and off-balance sheet banking. Journal of Banking \& Finance, 21(1), 55-87.

Angelini, P., \& Cetorelli, N. (2003) The effects of regulatory reform on competition in the banking industry. Journal of Money, Credit and Banking, 35(5), 663-84.

Arellano, M., \& Bover, O. (1995). Another look at the instrumental variable estimation of error-components models. Journal of Econometrics, 68(1), 29-51

Aydemir, R., \& Guloglu, B. (2017). How do banks determine their spreads under credit and liquidity risks during business cycles?. Journal of International Financial Markets, Institutions \& Money, 46, 147-157.

Aysan, A., Dalgic, C. H., \& Demirci, M. (2010). Macroeconomic, sector specific and bank specific determinants of net interest rate margin: what matters more for an emerging market economy? EcoMod2010 259600015, Istanbul.

Bernanke, B., \& Gertler, M. (1989). Agency costs, net worth and business fluctuations. American Economic Review, 79, 14-31.

Bernanke, B. \& Gertler, M. (1995). Inside the black box: The credit channel of monetary policy transmission. Journal of Economic Perspectives, 9 (4), 27-48.

Bernanke, B., Gertler, M., \& Gilchrist, S. (1996). The financial accelerator and the flight to quality. The Review of Economics and Statistics, 78 (1), 1-15.

Blundell, R., \& Bond, S. (1998). Initial conditions and moment restrictions in dynamic panel data models. Journal of Econometrics, 87(1), 115-143.

Chand, S., \& Sen, K. (2000). The business cycle, market structure and mark-ups: an Indian case study. Applied Economics Letters 7, 251-254.

Culha, A., \& Yalcın, C. (2005). The determinants of the price-cost margins of the manufacturing firms in Turkey. Working Papers 0515, Research and Monetary Policy Department, Central Bank of the Republic of Turkey.

Domowitz, I., Hubbard, R.G., \& Petersen, B.C. (1986a). Business cycles and the relationshipbetween concentration and price-cost margins. The Rand Journal of Economics, 17, 1-17.

Domowitz, I., Hubbard, R. G., \& Petersen, B. C. (1986b). The intertemporal stability of the concentration-margins relationship. Journal of Industrial Economics, 35, 13-34.

Erol, H. (2007). Bankalarda net faiz marjının belirleyicileri, risk duyarlılığı ve politika önerileri. Uzmanlık yeterlilik tezi, Türkiye Cumhuriyeti Merkez Bankası, Ankara.

Fungacova, Z. \& Poghosyan, T., (2011). Determinants of bank interest margins in Russia: Does bank ownership matter?. Economic Systems, 35(4), 481-495.

Gerlach, S., Peng, W., \& Shu, C. (2005). Macroeconomic conditions and banking performance in Hong Kong SAR: A panel data study, BIS Papers No 22.

Green, E. J., \& Porter, R.H. (1984). Non-cooperative collusion under Imperfect price İnformation. Econometrica, 52 (1), 87-100.

Haskel, J., Martin, C., \& Small, I. (1995). Prices, marginal cost and the business cycle. Oxford Bulletin of Economics and Statistics, 57(1), 25-41.

Hesse, H. (2007). Financial intermediation in the pre-consolidated banking sector in Nigeria. Policy Research Working Paper Series 4267, The World Bank.

Ho, T.S., \& Saunders, A. (1981). The determinants of bank interest margins: Theory and empirical evidence. Journal of Financial and Quantitative analysis, 16 (4), 581-600.

Kansoy, F. (2012). The determinants of net interest margin in the Turkish banking sector: Does bank ownership matter?. Journal of BRSA Banking and Financial Markets, 6(2), 13-49.

Kaya, T. Y. (2002). Türk bankacılık sektöründe karlılı̆̆ın belirleyicileri 1997-2000. Bankacılık Düzenleme ve Denetleme Kurumu Mali Sektör Politikaları Dairesi Çalışma Raporları, 4. 
Konar, Y. (2014). Factors explaining net interest margins and spreads in Turkish banking sector: Evidence from $2002-$ 2013 period. MSc. Finance Thesis, Tillburg University.

Lima, M. A., \& Resende, M. (2004). Profit margins and business cycles in the Brazilian industry: a panel data study. Applied Economics, 36 (9), 923-930.

Machin, S., \&Van Reenen, J. (1993). Profit margin and the business cycle: evidence from UK manufacturing firms. Journal of Industrial Economics, 41 (1), 29-50.

Maudos, J., \& De Guevara, J.F. (2004). Factors explaining the interest margin in the banking sectors of the European Union. Journal of Banking and Finance, 28(9), 2259-2281.

McShane, R. W., \& Sharpe, I. G. (1985). A time series/cross section analysis of the determinants of Australian trading bank loan/deposit interest margins: 1962-1981. Journal of Banking \& Finance, 9(1), 115-136.

Nekarda, C., \& Ramey, V. (2013). The cyclical behavior of the price-cost markup. NBER Working Paper No. 19099.

Oliveira Martins J., Scarpetta,S., \& Pilat, D. (1996). Mark-up pricing, market structure, and the business cycle. OECD Economic Studies, 27, pp. 71-105.

Ozdincer, B., \& Ozyıldırım, C. (2010). Türkiye bankacılık sektöründe net faiz marjlarının belirlenmesinde etkin faktörler: Türkiye analizi. İktisat İşletme ve Finans, 25(292), 9-27.

Portier, F. (1995). Business formation and cyclical markups in the French business cycle. Annals of Economics and Statistics, 37/38, 11-440.

Prince, Y. M., \& Thurik, A. R. (1992). Price-cost margins in Dutch manufacturing. De Economist, 140 (3), $310-335$.

Rotemberg, J., \& Saloner, G. (1986). A supergame-theoretic model of price wars during booms," American Economic Review, 76 (3), pp. 390-407.

Rotemberg, J., \& Woodford, M. (1991). Markups and the business cycle. NBER Macroeconomics Annual 1991, 6, 63140.

Saunders, A., \& Schumacher, L. (2000). The determinants of bank interest rate margins: An international study. Journal of International Money and Finance, 19(6), 813-832.

Turgutlu, E., (2010). Cyclical behavior of price-cost margins in the Turkish banking industry. Economic Modelling, 27, 368-374

Ugur, A., \& Erkus, H. (2010). Determinants of net interest margins of banks in Turkey. Journal of Economic \& Social Research, 12 (2), 101-118.

Yılmaz, M. H. (2017). Factors impacting bank net interest margin and the role of monetary policy: Evidence from Turkey. International Journal of Finance \& Banking Studies, 6(2), 1-23.

Yuksel, S., \& Zengin, S. (2017). Influencing factors of net interest margin in Turkish banking sector. International Journal of Economics and Financial Issues, 7(1), 178-191. 